\title{
Simulated Complexity: A New Classroom Simulation to Teach about Campaign- Finance Laws
}

Dick M. Carpenter II, University of Colorado, Colorado Springs

Joshua M. Dunn, University of Colorado, Colorado Springs

ABSTRACT Classroom simulations have become an increasingly popular instructional method in political science to increase student engagement, interest, and learning. This article describes a simulation designed to teach students about the complexities of campaignfinance systems, particularly disclosure requirements. In the simulation, students work in groups to convince others how to vote on a pending ballot measure. After spending more than $\$ 200$ on materials, groups then must register as ballot-issue committees and comply with state campaign-finance laws, including tracking contributions and expenditures and completing all required forms. The simulation ends with a debrief. Results from several years of debriefs are presented to discuss how students perceive the complexities of campaign-finance laws. Dominant themes include surprise by students in the complexities of these laws and the effects they have on political speech and association.

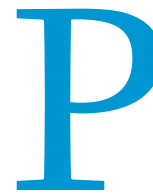
olitical science professors face challenges teaching an increasing number of students using traditional instructional strategies that students often consider uninteresting (Baranowski and Weir 2015). As a result, a growing number of faculty strive to develop creative techniques and implement experiential-learning methods in the classroom to maintain student engagement and increase learning (Baranowski and Weir 2015; Bromley 2013; Lay and Smarick 2006). Among these methods are simulations, which have become increasingly popular among political science faculty (Baranowski and Weir 2010, 2015; Fitzhugh 2014; Lay and Smarick 2006; Mariani 2007; Pappas and Peaden 2004) on a diverse set of topics (Auerbach 2013; Biziouras 2013; Bridge 2013; Frombgen et al. 2013; Glasgow 2015; Hunzeker and Harkness 2014; Jiménez 2015; Pallister 2015; Rinfret 2012; Switky 2014; Woessner 2015).

In political science, simulations have been found to be effective pedagogical tools in teaching civic education, campaign processes, electoral processes, and legislative processes (Bernstein

Dick M. Carpenter II is professor in the leadership, research, and foundations department and a faculty fellow in the Center for the Study of Government and the Individual at the University of Colorado, Colorado Springs. He can be reached at dcarpent@uccs.edu.

Joshua M. Dunn is professor and department chair in the political science department and the director of the Center for the Study of Government and the Individual at the University of Colorado, Colorado Springs. He can be reached at jdunn@uccs.edu. and Meizlish 2003; Caruson 2005; Deitz and Boeckelman 2012; Fuller 1973; Kathlene and Choate 1999; Lay and Smarick 2006; Pappas and Peaden 2004; Sands and Shelton 2010). Research indicates that simulations enhance student understanding of difficult materials, complex political concepts, interest, reality, skills, and motivation in a way that traditional methodologies often cannot achieve (Baranowski and Weir 2015; Caruson 2005; Fuller 1973; Mariani 2007; Pappas and Peaden 2004; Wedig 2010).

This article describes a new simulation activity for teaching about campaigns and elections, specifically focusing on campaign finance. It also reports the extent to which the simulation is linked to student perceptions of campaigns, elections, and political involvement, as indicated by results from several years of post-activity debriefs with simulation participants.

\section{SIMULATING CAMPAIGN FINANCE}

To create the simulation, we took inspiration from Sampson v. Buescher, a federal lawsuit on the topic of the complexities of campaign-finance laws. In brief, Sampson involved a small group of neighbors, led by Karen Sampson, who opposed the annexation of their Colorado neighborhood into a nearby town. After they posted a few handmade yard signs and talked to their neighbors, an annexation proponent sued them for operating as a ballot-issue committee without registering with the state. Colorado law required that any group that collectively spent more than $\$ 200$ to speak on a ballot issue was to register as an issue 
committee and comply with all of the sundry requirements that accompany it (e.g., completing campaign-finance forms, tracking and reporting all contributions and expenditures, and opening a bank account). The neighbors knew nothing of campaign-finance laws, and when they attempted to comply, they were soon overwhelmed by the requirements. They eventually challenged the federal constitutionality of the state's campaign-finance laws as a burden on free speech and association.

To introduce these issues to students, we designed a classroom simulation in which they are assigned to "community groups" that attempt to convince their neighbors how to vote on a forthcoming ballot issue. As far as the students know, this is the sum total of their task at the beginning of the exercise. It is only when each group spends more than $\$ 200$ that the campaign-finance element is triggered and they must comply with all of the various requirements. compliance within the context of campaign-finance disclosure laws, similar issues may be present with compliance in other contexts, such as opening a business, running a large public fundraiser, and other circumstances in which citizens must navigate a potentially challenging bureaucratic landscape. Thus, the framework of our simulation could be adapted to numerous other contexts.

\section{HOW IT WORKS}

This section briefly describes simulation activity. Detailed instructions and materials are provided in the online appendix.

At the beginning of a two-hour-and-4o-minute class, students are assigned to one of multiple groups (ideally, four to five students per group). They are told that their task is to determine a way to convince their neighbors how to vote on a measure that will appear on the ballot six days hence. Each group is given a

\section{As such, the exercise is designed to help students-who typically receive a disproportionate exposure to theory in political science-gain greater awareness and appreciate the practical realities of (1) engaging other people on issues; and (2) a little-known element of electoral campaigns-campaign-finance laws-particularly in the context of ballot-issue campaigns (Carpenter 2009).}

The focus of the simulation is twofold: (1) introducing campaign-finance laws-with a particular emphasis on disclosureand compliance requirements associated with these laws; and (2) compelling students to think about how to engage their fellow citizens. As such, the exercise is designed to help students-who typically receive a disproportionate exposure to theory in political science-gain greater awareness and appreciate the practical realities of (1) engaging other people on issues; and (2) a littleknown element of electoral campaigns-campaign-finance laws-particularly in the context of ballot-issue campaigns (Carpenter 2009).

Campaign finance, of course, is a large and debated topic, spanning candidate and ballot-issue contexts; recent US Supreme Court decisions (e.g., Citizens United v. FEC); the role of money in politics (Gaughan 2016; Gerken 2014; Krumholz 2013; Mayer 2016); and the efficacy of disclosure (Hasen 2011; Munger 2009; Primo 2013; Primo and Milyo 2006; Wood and Spencer 2016)-to name only a few. By necessity, a simulation created to be implemented within the confines of one class meeting must be narrowly focused. Thus, drawing on Sampson v. Buescher and placed within the context of discussion and debates about compliance with disclosure in ballot-issue campaigns (Carpenter and Milyo 20122013; Gardener 2012; Kang 2013; Milyo 2007; Youn 2013), we chose to focus the simulation on the experience of common citizens rather than experienced political participants.

This is not to ignore issues of disclosure (or its relative absence) associated with corporations, unions, large nonprofits, and other entities in the wake of Citizens United (Dowling and Wichowsky 2013; Potter and Morgan 2013; Torres-Spelliscy 2011). We expect these issues to be discussed among other disclosure-related topics in which our simulation would be placed, and perhaps someone else will develop and report on a simulation focused on "dark-money" campaigns. Although we focus the simulation on scenario to guide their actions. Some groups are supposed to convince their neighbors to vote for and others to vote against the measure. The activity lasts two hours. The first half-hour is dedicated to groups planning their campaign efforts. The remaining time is divided into six 15-minute blocks, each representing one day, during which students implement their plans.

Materials are purchased from a "store" using the money that each member of each group is given. The reality of the simulation is heightened by using actual materials, such as t-shirts and fabric markers. As groups make purchases from the store, the total money spent is tracked by storekeepers to determine when a group exceeds the $\$ 200$ threshold. When this happens, the activity stops and groups are introduced to the campaign-finance requirements with which they now are required to comply. This is accomplished by giving each group a state's actual multi-hundredpage campaign-finance manual, as well as all relevant forms (available on state websites).

They also are provided the "assistance" of another person in the room to whom they were not introduced at the beginning of the simulation: a representative of the "secretary of state." Much like a state elections division, the representative is available to answer questions as students complete the necessary campaignfinance documents. The representative also tracks mistakes made by groups as they submit (or do not submit) the required forms and tallies fines. When we implement this activity, we fill this role with a local attorney who is an expert in campaign-finance law.

After the simulation resumes, groups have two responsibilities: (1) designing materials for what are now officially campaigns, and (2) complying with state campaign-finance laws. To further increase the realism of the activity, each "day" in the simulation introduces new complexities that require greater attention to campaign-finance laws, including receiving unsolicited donations and anonymous cash contributions, offers to 
pay for political rallies, and requirements to submit necessary forms by prescribed deadlines. Many but not all of these complexities require that groups review the laws to determine what to do.

After the activity, we lead a debrief during which the instructor solicits perspectives from students about (1) the activity, and (2) the political phenomenon that the activity is designed to simulate. Results of these debriefs are reported in the next section as a measure of the simulation's effects. The simulation ends by asking the representative from the secretary of state's office to review errors made by the groups and announce the amount in fines that each group must pay. of each of the three themes is briefly discussed in the following subsections.

\section{Burdensome}

During the first 30 minutes of the simulation, when groups plan their campaign, it is common to hear students talk about the beliefs and principles they want their campaign to convey and then turn to specific strategies for conveying those to potential voters. During the first day, that wish is translated into enthusiasm for creating campaign materials. In every iteration of this simulation, we observe that students genuinely enjoy generating political speech. However, we also consistently observe students

\section{We completed an inductive analysis of the debrief comments and discerned three dominant themes: participants find the simulation's disclosure requirements (1) incredibly burdensome, (2) potentially chilling on speech and association, and (3) utterly mystifying.}

\section{DEBRIEF RESULTS}

In the years that we have implemented this simulation activity (we designed it in 2007), the debrief responses typically are consistent and unequivocal. We completed an inductive analysis of the debrief comments and discerned three dominant themes: participants find the simulation's disclosure requirements (1) incredibly burdensome, (2) potentially chilling on speech and association, and (3) utterly mystifying. It is far different than the idealized campaign environment they learn about in typical classes as well as other campaign simulations that lack a campaignfinance element.

Table 1 indicates the percentage of comments per theme made during debriefs. Whereas burdens associated with the campaign-finance regulations clearly dominated the students' comments, references to potential costs in the form of chilling speech and association also represented a non-trivial percentage of their observations. Although mentioned comparatively less often than the other themes, confusion and uncertainty associated with the disclosure laws emerged as a clear theme during the inductive coding of the comments. The percentages in the table do not total $100 \%$ because debrief discussions yielded comments that did not converge around identifiable themes. These comments included "I really liked this activity" and "The activity shows the benefits of contributions." The substance

\section{Table 1}

Percentage of Debrief Comments per Theme

\begin{tabular}{lcl}
$\begin{array}{l}\text { Theme } \\
\text { Burden }\end{array}$ & Percentage & \multicolumn{1}{c}{ Exemplar Participant Quote } \\
\hline Costs & 29 & $\begin{array}{l}\text { "If this is what it's really like, then these } \\
\text { campaigns undergo a lot of red tape and } \\
\text { bureaucracy." }\end{array}$ \\
\hline Mystifying & 12 & $\begin{array}{l}\text { "People donated but we did not use it } \\
\text { because the government forms limit the } \\
\text { ability to get your message out-it limits } \\
\text { free speech." }\end{array}$ \\
\hline "We had money, but it was difficult to \\
know if you can spend it."
\end{tabular}

switch quickly from the pleasure of exercising First Amendment rights to the pain of compliance. When the campaign-finance disclosure requirements are introduced, the initial plans often are significantly disrupted as participants grapple with the regulatory requirements. The most common response is for campaigns to dedicate one group member full time to disclosure requirements while the others continue with their original plans; however, they soon discover that one person often is not enough. "We dedicated several people just to do forms," one student described.

Students often reflect on the burdens from the perspective of the average citizen. As one student commented, "It's easy to make flyers and signs, but it's hard to monitor your actions to avoid getting into trouble." Or, as another described, "There are so many hoops to jump [through] - a regular person would not want to do it." In fact, as the simulation proceeds, groups sometimes refuse to accept contributions. One campaign spokesperson noted, "When donations came in, we dreaded it. We eventually said we did not want them anymore because we had to constantly change our paperwork." Every time we have implemented the simulation, at least one person makes an observation like this: "Money is important, but I can't go through this manual and know what to do. I would need a lawyer and accountant on staff to make sure I did not make any mistakes."

\section{Chilling Speech and Association}

During debriefs, simulation participants also commonly infer two effects from these burdens: a chill on speech and the reduced likelihood of political participation. For many, speech is reduced by refusing to accept contributions-even legal ones-which then limits the ability to speak through the production of campaign materials. As one participant described, "We rejected or returned contributions-they weren't worth the hassle." This sentiment is repeated in debriefs every time we run the simulation. A related effect occurs when groups intentionally hold back funds, thinking they will have to pay fines at the end of the simulation. In other words, rather than spending money on speaking, they wait to spend money on fines. As one participant described it, "You need to run a campaign by saving money for a legal defense." We do not tell participants about the potential of being fined for mistakes; they often discover it on their own by reading the manual and then adjust their behavior spontaneously. 
Just as students see implications for speech, they also see burdens on political involvement, particularly their own. "Having to fill out all of this stuff makes me never want to do this again" is a common refrain during debriefs. Some generalize the effects ("This dampens people's willingness to participate") whereas others personalize them ("If I knew this is what a campaign was like, I would be less likely to get involved"). Participants mostly ascribe reduced involvement to regulatory requirements, but others recognize the potential for campaign-finance laws to be used as a weapon, thereby creating a disincentive to be involved. As one astute participant discovered, "You can really use these laws to hurt the other side-watching their disclosed forms for mistakes to generate fines and even sabotaging them with illegal contributions." Indeed, we have seen group members approach the secretary of state representative to report on the activities of other groups. This is a feature of the simulation that even mimics actual circumstances. When we wrote this article, for example, Colorado newspapers were reporting on how a local conservative political activist was using campaign-finance disclosure laws to bully opponents (Luning 2017; Schrader 2017).

We always implement the debriefs before we ask our campaignfinance attorney to describe to the students the extent of their mistakes on the forms and the monetary consequences they would incur in the form of fines. Thus, all of the students' comments are voiced before they fully understand the implications of campaign-finance disclosure systems. Every time we run the simulation, groups violate from five to 20 provisions of the law, generating fines ranging from a few thousand dollars to almost $\$ 100,000$. The announcement of mistakes and fines typically is met with nervous laughter or an occasional pitiful defense such as, "But we're just normal people."

\section{Utterly Mystifying}

The fear of violating the law typically leads participants to spend significant time pouring over the campaign-finance manual when accepting a donation or making an expenditure while asking one another, "We did not get receipts for our expenditures; is that legal?" and "When did we get this money?" The requirements make them exceedingly wary about anything related to their campaign. When receiving donations as part of the simulation, it is common to hear students say, "Wait, ...can we take this?" The same sentiments are expressed in the debriefs. One student observed, "It was difficult to figure out what we could and could not accept." In fact, this type of observation is common for this theme, as one participant said, "It was painful to get a donation; we had to figure out if we could use it."

\section{CONCLUSION}

Simulations are designed to help students develop a deeper and more concrete understanding of a particular topic, and comments from participants in our simulation suggest that it is achieving the desired ends. Through the activity, students learn that the requirements of a modern campaign are more complex than the idealized models that often are portrayed. They also understand more practically how money is the lifeblood of political speech and that it is a "two-edged sword."

A potentially efficacious change to the activity would be to expand it beyond one class meeting and then measure its effects. A longer simulation would allow for the inclusion of a voter element such that hypothesized benefits of disclosure could be measured and discussed with students, particularly in relation to the types of costs discussed previously. It also could make possible original research to contribute additional findings to a current and important discussion/debate about disclosure requirements (Carpenter et al. 2014; Carpenter and Milyo 2012-2013; Gilbert and Aiken 2015; Mayer 2014; Wood and Spencer 2016).

Finally, there is always a risk when programming simulations into the curriculum-we can never be certain until the first implementation whether students will find it engaging if not enjoyable. For those interested in using the simulation described herein, our observation has been that students are engaged throughout the activity and frequently express positive comments weeks later, when completing course evaluations. We expect that others who use this simulation will have a similar experience.

\section{SUPPLEMENTARY MATERIAL}

To view supplementary material for this article, please visit https://doi.org/10.1017/S1049096517002323 =

\section{REFERENCES}

Auerbach, Arthur H. 2013. "United States Supreme Court Confirmation Simulation: Learning through the Process of Experience." PS: Political Science \& Politics 46 (4): 808-12.

Baranowski, Michael K., and Kimberly A. Weir. 2015. "Political Simulations: What We Know, What We Think We Know, and What We Still Need to Know." Journal of Political Science Education 11 (4): 391-403.

. 2010. "Power and Politics in the Classroom: The Effect of Student Roles in Simulations." Journal of Political Science Education 6 (3): 217-26.

Bernstein, Jeffrey L., and Deborah S. Meizlish. 2003. "Becoming Congress: A Longitudinal Study of the Civic Engagement Implications of a Classroom Simulation." Simulation Gaming 34 (2): 198-219.

Biziouras, Nikolaos. 2013. "Midshipmen Form a Coalition Government in Belgium: Lessons from a Role-Playing Simulation." PS: Political Science \& Politics 46 (2): 400-405.

Bridge, Dave. 2013. "The Settlement Game: A Simulation Teaching Institutional Theories of Public Law." PS: Political Science \& Politics 46 (4): 813-17.

Bromley, Pam. 2013. "Active Learning Strategies for Diverse Learning Styles: Simulations Are Only One Method." PS: Political Science \& Politics 46 (4): 818-22.

Carpenter, Dick M. 2009. "Mandatory Disclosure for Ballot Initiative Campaigns." Independent Review 13 (4): 567-83

Carpenter, Dick M., and Jeff Milyo. 2012-2013. “The Public's Right to Know Versus Compelled Speech: What Does Social Science Research Tell Us about the Benefits and Costs of Campaign Finance Disclosure in Non-Candidate Elections?" Fordham Urban Law Journal 40 (2): 603-38.

Carpenter, Dick M., David Primo, Pavel Tendetnik, and Sandy Ho. 2014 "Disclosing Disclosure: Lessons from a 'Failed' Field Experiment." The Forum $12(2): 343-56$.

Caruson, Kiki. 2005. "So, You Want to Run for Elected Office? How to Engage Students in the Campaign Process without Leaving the Classroom." PS: Politica Science \& Politics 38 (2): 305-10.

Deitz, Janna L., and Keith Boeckelman. 2012. "Simulating 2008: A Mock Presidential Election's Impact on Civic Engagement." PS: Political Science \& Politics 45 (4): 743-7.

Dowling, Conor M., and Amber Wichowsky. 2013. "Does It Matter Who's Behind the Curtain? Anonymity in Political Advertising and the Effects of Campaign Finance Disclosure." American Politics Research 41 (6): 965-96.

Fitzhugh, Emma. 2014. Facilitating Student Discussion: The Case of a Political Science Class. Master's Thesis. Ypsilanti: Eastern Michigan University.

Frombgen, Elizabeth, David Babalola, Aaron Beye, Stacey Boyce, Toby Flint, Lucia Mancini, and KatieVan Eaton. 2013. "Giving up Control in the Classroom: Having Students Create and Carry out Simulations in IR Courses." PS: Political Science \& Politics 46 (2): 395-9.

Fuller, Jack W. 1973. "Simulation in a Political Science Classroom." Improving College and University Teaching 21 (4): 284-5

Gardener, Jacob. 2012. "Sunlight without Sunburns: Balancing Public Access and Privacy in Ballot Measure Disclosure Laws." Boston University Journal of Science $\mathcal{E}$ Technology Law 18 (2): 262-307. 
Gaughan, Anthony J. 2016. "The Forty-Year War on Money in Politics: Watergate, FECA, and the Future of Campaign Finance Reform." Ohio State Law Journal 77 (4): $791-837$.

Gerken, Heather K. 2014. "The Real Problem with Citizens United: Campaign Finance, Dark Money, and Shadow Parties." Marquette Law Review 97 (4): 904-23.

Gilbert, Michael D., and Benjamin F. Aiken. 2015. "Disclosure and Corruption." Election Law Journal 14 (2): 148-64.

Glasgow, Derek. 2015. "Political Theory Simulations in the Classroom: Simulating John Locke's Second Treatise of Government." PS: Political Science \& Politics 48 (2): $368-72$

Hasen, Richard L. 2011. "Chill Out: A Qualified Defense of Campaign Finance Disclosure Laws in the Internet Age." Irvine: University of California School of Law.

Hunzeker, Michael A., and Kristen A. Harkness. 2014. "The Strategy Project: Teaching Strategic Thinking through Crisis Simulation.” PS: Political Science $\mathcal{E}$ Politics 47 (2): 513-17.

Jiménez, Luis F. 2015. “The Dictatorship Game: Simulating a Transition to Democracy.” PS: Political Science \& Politics 48 (2): 353-7.

Kang, Michael. 2013. "Campaign Disclosure in Direct Democracy." Minnesota Law Review 97: 1700-729.

Kathlene, Lyn, and Judd Choate. 1999. "Running for Elected Office: A Ten-Week Political Campaign Simulation for Upper-Division Courses.” PS: Political Science \& Politics 32 (1): 69-76.

Krumholz, Sheila. 2013. "Campaign Cash and Corruption: Money in Politics, Post-Citizens United." Social Research 8o (4): 1119-34.

Lay, J. Celeste, and Kathleen J. Smarick. 2006. "Simulating a Senate Office: The Impact on Student Knowledge and Attitudes." Journal of Political Science Education $2(2): 131-46$

Luning, Ernest. 2017. "Matt Arnold Scores Win Against County GOP Amid Charges He's Waging Proxy State Chair Battle." Colorado Statesman, March 9. Available at www.coloradostatesman.com/matt-arnold-scores-win-againstcounty-gop-amid-charges-waging-proxy-state-chair-battle.

Mariani, Mark D. 2007. "Connecting Students to Politics through a Multi-Class Campaign Simulation." PS: Political Science \& Politics 40 (4): 789-94.

Mayer, Jane. 2016. Dark Money. New York: Doubleday.

Mayer, Lloyd Hitoshi. 2014. "Politics and the Public's Right to Know." Election Law Journal 13 (1): 138-59.

Milyo, Jeffrey. 2007. "Campaign Finance Red Tape: Strangling Free Speech and Political Debate." Arlington, VA: Institute for Justice.
Munger, Michael C. 2009. "Locking up Political Speech: How Electioneering Communications Laws Stifle Free Speech and Civic Engagement." Arlington, VA Institute for Justice.

Pallister, Kevin. 2015. "Teaching Globalization and Development through a Simulation." PS: Political Science \& Politics 48 (2): 364-7.

Pappas, Christine, and Charles Peaden. 2004. "Running for Your Grade: A Six-Week Senatorial Campaign Simulation.” PS: Political Science \& Politics 37 (4): 859-63.

Potter, Trevor, and B. B. Morgan. 2013. "The History of Undisclosed Spending in U.S. Elections and How 2012 Became the Dark Money Election." Notre Dame Journal of Law, Ethics, and Public Policy 27: 383-479.

Primo, David M. 2013. "Information at the Margin: Campaign Finance Disclosure Laws, Ballot Issues, and Voter Knowledge." Election Law Journal 12 (2): 114-29.

Primo, David M., and Jeffrey Milyo. 2006. "Campaign Finance Laws and Political Efficacy: Evidence from the States." Election Law Journal 5 (1): 23-39.

Rinfret, Sara R. 2012. "Simulating City Councils: Increasing Student Awareness and Involvement." PS: Political Science \& Politics 45 (3): 513-15.

Sands, Eric C., and Allison Shelton. 2010. "Learning by Doing: A Simulation for Teaching How Congress Works.” PS: Political Science \& Politics 43 (1): 133-8.

Schrader, Megan. 2017. “A Sordid Tale of Colorado Campaign Finance.” Denver Post, April 4. Available at www.denverpost.com/2017/04/04/a-sordid-tale-ofcolorado-campaign-finance.

Switky, Bob. 2014. "Simulating a Foreign Policy Dilemma: Considering US Humanitarian Intervention." PS: Political Science \& Politics 47 (3): 682-6.

Torres-Spelliscy, Ciara. 2011. "Has the Tide Turned in Favor of Disclosure? Revealing Money in Politics after Citizens United and Doe v. Reed." Georgia State University Law Review 27 (4): 1057-104.

Wedig, Timothy. 2010. "Getting the Most from Classroom Simulations: Strategies for Maximizing Learning Outcomes.” PS: Political Science $\mathcal{E}$ Politics 43 (3): 547-55

Woessner, Matthew. 2015. "Teaching with SimCity: Using Sophisticated Gaming Simulations to Teach Concepts in Introductory American Government." PS: Political Science \& Politics 48 (2): 358-63.

Wood, Abby K., and Douglas M. Spencer. 2016. "In the Shadows of Sunlight: The Effects of Transparency on State Political Campaigns.” Election Law Journal 15 (4): 302-29.

Youn, Monica. 2013. "Proposition 8 and the Mormon Church: A Case Study in Donor Disclosure.” George Washington Law Review 81: 2108-54. 


\section{JOINTHE AMERICAN POLITICAL SCIENCE ASSOCIATION.}

Access the latest scholarship in political science.

Advance your career with APSA scholarly teaching resources \& opportunities.

Learn more aboutAPSA programs, grants, awards, etc.

Find jobs, postyour CV and access APSA career services.

Network with more than $6,000+$ political scientists at the Annual Meeting!
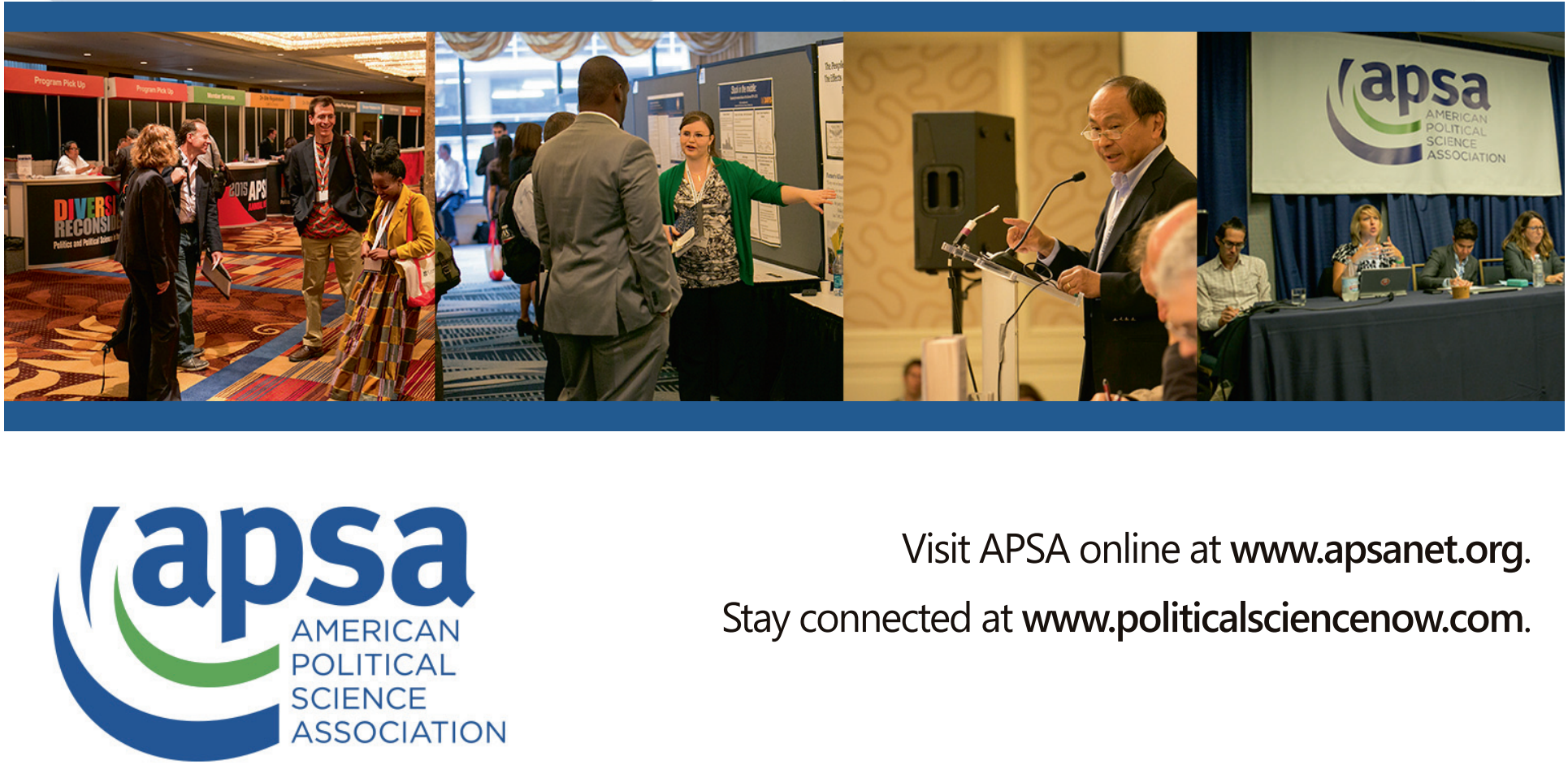

Visit APSA online at www.apsanet.org. Stay connected at www.politicalsciencenow.com. 